\title{
The Development and Validation of a Figural Scientific Creativity Test for Preschool Pupils
}

\author{
Mui Ken Chin, Nyet Moi Siew \\ Faculty of Psychology and Education, Universiti Malaysia Sabah, Kota Kinabalu, Malaysia \\ Email: lilycmk2007@yahoo.com, snyetmoi@yahoo.com
}

Received 25 June 2015; accepted 20 July 2015; published 23 July 2015

Copyright (C) 2015 by authors and Scientific Research Publishing Inc.

This work is licensed under the Creative Commons Attribution International License (CC BY). http://creativecommons.org/licenses/by/4.0/

(c) $\underset{\mathrm{EY}}{\mathrm{EP}}$ Open Access

\section{Abstract}

Testing creativity in general has been well researched but little has been reported on the development of instruments to test scientific creativity among preschool pupils. This study described the development and validation of a Figural Scientific Creativity Test (FSCT) for preschool pupils. The FSCT consisted of six items which were constructed based on Scientific Creativity Structure Model and scored using an adapted Torrence Test of Creative Thinking. The items were developed through three dimensions called the product (scientific knowledge, scientific phenomena and scientific problem), the process (imagination and thinking) and the trait (fluency, originality, elaboration, abstractness of title and resistance to premature closure). All the items were developed and validated through analysis of item response data of 30 six-year-old preschool pupils in Kota Kinabalu district. Item analyses were conducted to check on item discrimination, Cronbach Alpha internal consistency coefficient, item-total correlations, agreement between scorers, construct related validity, content validity, face validity, and acceptability to pupils. All items showed discrimination coefficient range from 0.22 to 0.40 . The Cronbach Alpha internal consistency coefficient was found to be 0.806 . The item-total correlations range was within 0.541 to 0.866 . The correlations between scorers varied from 0.780 to 0.933 . FSCT was found to have a total of six items on one factor as a result of the exploratory factor analysis. The item analysis suggested that FSCT could be a reliable and valid instrument in assessing scientific creativity of six-year-old preschool pupils in preschool classrooms.

\section{Keywords}

Figural Scientific Creativity Test, Preschool Pupils, Scientific Creativity Structure Model, Torrance Test of Creative Thinking 


\section{Introduction}

As the world is entering a new era, creativity is not just becoming increasingly important (Pink, 2005), but it seems that "our future is now closely tied to human creativity" (Csikszentmihalyi, 1996). Gardner (2010), in his Five Minds for the Future, argued for the crucial role of creativity, as one of the five cognitive abilities that leaders of the future should seek to cultivate. In order to prepare for the future, the Malaysian Ministry of Education (MOE) has introduced "The Education Development Plan" in 2012. This plan outlines the directions for the education system in Malaysia from 2013 to 2025 (Ministry of Education, 2012). Through this plan, there are six key attributes in the student aspirations that needed by every student to be globally competitive and one of the attributes is able to think critically and creatively.

The efforts of the MOE to develop creative thinking skills among preschool pupils have been started with the implementation of National Preschool Curriculum since 2001 (Curriculum Development Centre, 2001) and the newly-implemented National Preschool Curriculum Standard (NPCS) which was introduced in 2010 (Curriculum Development Centre, 2010). In these preschool curriculums, science is one of the disciplines that can make a contribution to the achievement of these goals.

Many researchers have concluded that creativity is domain-specific (Albert, 1983; Gardner, 1983; Feldman, 1986; Han, 2003; Kaufman \& Baer, 2008). Nickerson (1999) stressed the importance of domain-specific knowledge as a determinant of creativity and felt it was generally underestimated. According to Hu and Adey (2002), a domain specific creativity such as scientific creativity was worth attention as scientific research required creativity and went beyond what was already known. Furthermore, during science activities, pupils are required to solve problems by producing several possible methods. Thus, Aktamış and Ergin (2006) pointed out that science lesson was one of the most important lessons in which pupils could be nurtured with all the dimensions of the scientific creativity.

Although many researches have been done, there are still some limitations of the research on scientific creativity. Most of the researchers chose to measure students' creativity in specific domains such as biology (Carson, 2011), chemistry (Cox \& Jones, 2011), and mathematics (Siew \& Chong, 2014; Sriraman, 2005) rather than to assess students' scientific creativity in general. Moreover, most of the respondents in the scientific creativity research were elementary (Mohamed, 2006), secondary (Hu \& Adey, 2002; Liang, 2002) and high school students (Silva, Fadel, \& Wechsler, 2013). There are not many published scientific creativity instruments that focus on preschool level. Ignoring children's scientific creativity in the preschool can be detrimental for these children in subsequent grade levels. Therefore, more attention is needed to shift the focus of researchers from the discussion of scientific creativity toward preschool level. Identifying scientific creativity in preschool can help children make the best use of their potential. Thus, educators can better serve the children's needs through providing appropriate teaching methods and learning opportunities that promote scientific creativity.

In Malaysia, one of the major limitations of research on scientific creativity in preschool level is the lack of instruments that suit the National Preschool Curriculum Standard and Malaysian's culture. Hence, this study aimed to develop a Figural Scientific Creativity Test (FSCT) which was constructed based on Scientific Creativity Structure Model (SCSM) and scored using an adapted Torrence Test of Creative Thinking (TTCT) to measure six-year-old preschool pupils' scientific creativity and ascertain the reliability and validity of this test.

\section{Scientific Creativity Structure Model (SCSM)}

The SCSM (Figure 1) proposed by Hu and Adey (2002) was based on Guilford's (1956) Structure of Intellect Model. The SCSM structure was designed as a theoretical foundation for cultivating, researching and measuring scientific creativity. The three dimensional SCSM model consisted of 24 cells with 4 product dimensions $\times 3$ trait dimensions $\times 2$ process dimensions (Figure 1 ) described below.

\subsection{Product Dimension}

Hu and Adey (2002) consider four potential scientific products; science problem, science knowledge, science phenomena, and technical product. A science problem is an issue or problem situation related to science. Lubart (1994) suggested that problem solving during an activity can enhance creativity as people try to create solutions to the problem. Science knowledge is the understanding of science and certain basic science concepts. Science phenomena are observable events or occurrences. In the present study, the researcher has eliminated the technical product during development of Figural Scientific Creativity Test (FSCT) by considering that less emphasis is given to this product dimension in the preschool's science curriculum. 


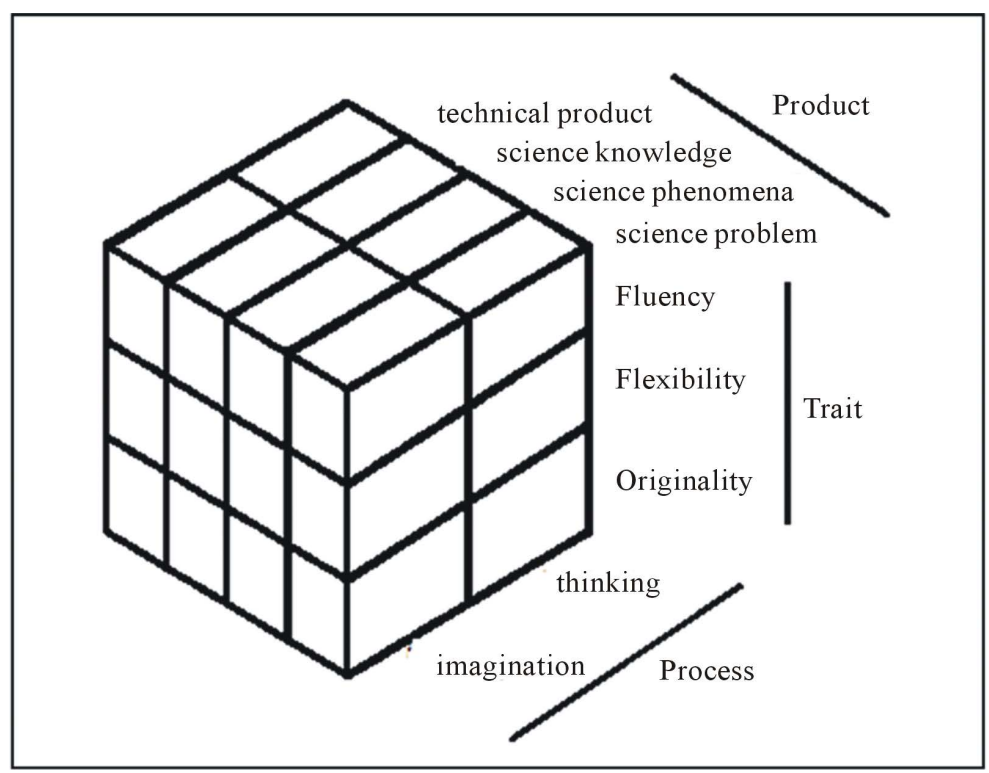

Figure 1. Scientific creativity structure model.

\subsection{Trait Dimension}

Torrance (1990) considered three characteristics (or traits) of the creative person: fluency, flexibility and originality. Fluency is a creative ability that allows a person to produce many ideas or solutions (Meador, 1997). Flexibility is the ability to bring different approaches to a problem, think of ideas in different categories, or view a situation from several perspectives (Davis \& Rimm, 2004). Originality is the rare answer which occurs only occasionally in a given population (Meador, 1997). The SCSM is based on these three subscales as the trait dimension. However, Torrance, Ball and Safter (2008) improved the three subscales by introducing five norm reference measures: fluency, originality, elaboration, abstractness of title, and resistance to premature close. Thus, the development of FSCT is based on these five norm references.

\subsection{Process Dimension}

Creative imagination and creative thinking are attributes of the third SCSM dimension. Creative imagination is the ability to form new images in the mind that are not directly captured through the senses of sight, sound, touch, taste or hearing. Creative thinking is the process of producing novel or innovative thoughts.

In the present study, the FSCT developed was based on the improved Scientific Creativity Structure Model for FSCT (Figure 2).

\section{Methods}

\subsection{Study Sample}

The study was conducted with six-year-old preschool pupils in one urban MOE's preschool in Kota Kinabalu, Sabah. 30 preschool pupils included in the study were determined through purposive sampling. The criterion that "sample needs to be at least five times of the item number" (Coakes, 2005) was followed to determine the sample. There were six items in the FSCT, and at least five times the sample size of this study.

\subsection{Description of the FSCT}

FSCT required responses that were mainly pictorial in nature, a small amount of writing was required from the preschool pupils when they were directed to label or name the pictures they have drawn. The test was designed for individual administration in small groups of 5 to 10 pupils. Each item required ten minutes to complete and the actual drawing time was 60 minutes. Test requirements in these instruments were the same as for other examinations. The examiner sought not only to make the pupils feel at ease but also to work hard to complete the 


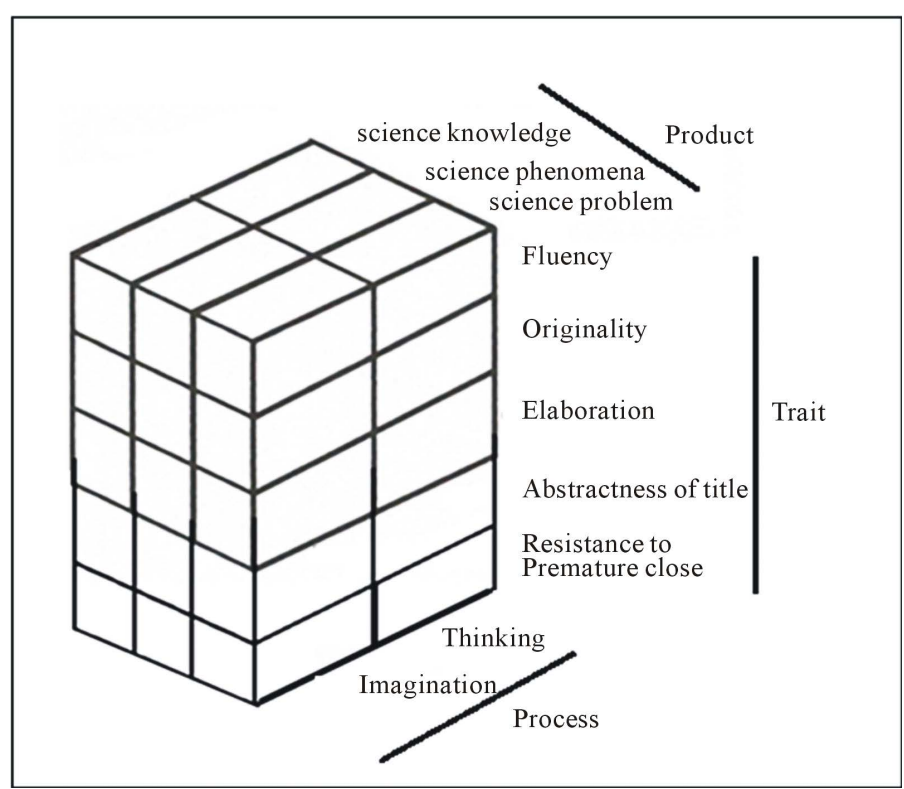

Figure 2. The improved scientific creativity structure model for FSCT.

tasks. A general instructions were printed on the front page of the instrument:

\footnotetext{
I believe you will have a lot of fun doing the activities we have planned in this booklet. You have 6 different tasks. Each task investigates different scientific skills, giving you a chance to draw and see how good you are thinking of new ideas and solving problems. Use the imagination and thinking ability that you have to draw your pictures and I hope that you will enjoy yourself. Please try to complete all the tasks in one lesson (60 minutes). I will read the task and if you have questions, please raise up your hand and I shall offer help. Please write down your name, class, school and today's date on the answer sheet before you begin.
}

While administering the test, instructors had to give instructions to the preschool pupils in order to stimulate all the trait dimensions of scientific creativity. For instance, instructions such as "draw as many correct objects or pictures as you can" to stimulate fluency. As for originality, "think as many uncommon objects or things that less people will think of". To stimulate elaboration, "put as many ideas into your drawing and make the pictures tell as complete and interesting story as you can". For abstractness of title, "make an interesting and unusual title in each of your drawing" and as for resistance to premature closure, "make your pictures or objects as complete as you can by adding to and building up your first idea". Torrance, Ball and Safter (2008) suggested that instructors could help preschool pupils who were unable to write their own titles or labels in the creativity test. Thus, instructors in this study interviewed each pupil briefly to obtain titles or labels and write down in the answer sheet in order to obtain a more reliable scoring of the pictures.

\subsection{Development of FSCT}

FSCT were constructed based on improved SCSM (Figure 2). The items were approached in three dimensions consisting of the product (scientific knowledge, scientific phenomena and scientific problem), the process (imagination and thinking) and the trait (fluency, originality, elaboration, abstractness of title and resistance to premature closure). There were six items in the FSCT: scientific knowledge (two items), scientific problem (two items) and scientific phenomena (two items).

All the items were developed based on the National Preschool Curriculum Standard which was introduced in 2010 (Curriculum Development Centre, 2010). The items were related to real world activity, which could make the pupils draw true scientific products. The real world problems were used as it had a stronger correlation with other domains in creative performance (Okuda, Runco, \& Berger, 1991). All the items were reviewed by a group of experts before the final versions were designed. The instrument was presented in Malay language to ensure 
the samples understood each item before they responded.One example of an answer was given for each item in order to help preschool pupils understand what was required. The description of each item in FSCT is presented below:

\section{Item 1}

A plastic bottle cap floats on the water surface. How do you make the plastic bottle cap sinks in the water? (Example: tied the plastic bottle cap with coin)

The purpose of the first item is to measure the degree of sensitivity to scientific problems. Furthermore, this item aims to raise new possibilities from a new angle, and pupils need to imagine and make real advances in science. This item covers scientific problem (product dimension), fluency, originality, elaboration, abstractness of title and resistance to premature closure (trait dimension), and thinking and imagination (process dimension).

\section{Item 2}

You found a magnet on the floor. Think as many materials or objects as possible that are not attracted to the magnet.

(Example: wood is not attracted to the magnet)

This item is to measure pupils' scientific knowledge of a magnet. This item covers scientific knowledge (product dimension), fluency, originality, elaboration and abstractness of title (trait dimension) and thinking (process dimension).

\section{Item 3}

A glass of orange juice spilled on the floor. Show in your drawing on how the orange juice can be dried up. (Example: wipe the orange juice with handkerchief)

This item is designed to measure pupils' ability to solve scientific phenomena. The item covers scientific phenomena (product dimension), fluency, originality, elaboration, abstractness of title and resistance to premature closure (trait dimension), and thinking and imagination (process dimension).

\section{Item 4}

While walking to school. Ali saw shadows around him. Show how shadows are formed.

(Examples: place a book between the sun and the floor)

The forth item is designed to measure the ability to describe creatively the scientific natural phenomena. Based on SCSM, the item covers scientific phenomena (product dimension), fluency, originality, elaboration, abstractness of title and resistance to premature closure (trait dimension) and thinking and imagination (process dimension).

\section{Item 5}

You have mixed some materials and objects in a basin filled with water. Think as many materials or objects as possible that are not soluble in the water after stirring with spoon.

(Example: stone is not soluble in the water).

This item is designed to measure scientific knowledge of materials or objects that are soluble and insoluble in water. This item covers scientific knowledge (product dimension), fluency, originality, elaboration and abstractness of title (trait dimension), and thinking (process dimension). Hu and Adey (2002) stated that within the limits of a paper and pencil test, it proved impossible to write items about scientific knowledge and imagination. Thus, the assessment of imagination is not included in this item.

\section{Item 6}

You have mixed salt with the sand. How do you separate the sand from the mixture?

(Example: add mineral water to the mixture and stir with spoon).

This item is a problem solving task on science. It is designed to measure creative scientific problem solving ability. The respondents were required to think of the problem in a scientific context. The item covers scientific problem (product dimension), fluency, originality, elaboration, abstractness of title and resistance to premature closure (trait dimension) and thinking and imagination (process dimension).

\subsection{Scoring Procedures}

Items 1, 3, 4 and 6 were scored for five subscales of trait dimension: fluency, originality, elaboration, abstractness of title and resistance to premature closure score. As for items 2 and 5 , the scores were obtained for four subscales of trait dimension only: fluency, originality, elaboration and abstractness of title. Resistance to premature closure was eliminated from items 2 and 5 as suggested by a creativity expert. This is because the items were related to scientific knowledge which were hard for the respondents to give available information from a 
variety of perspectives in their drawing. The scoring criteria adapted from Torrance, Ball and Safter (2008) for each subscale of trait dimension is shown in Table 1.

\section{Findings}

\subsection{Item Discrimination}

The discrimination coefficient (DisCo) of FSCT was computed. Jandaghi (2010) suggested of using Disco for open questions in the research. On the other hand, Matlock-Hetzel (1997) stated that DisCo has advantages compared to discriminant indices as DisCo includes the entire test scorer in the computation instead of only the upper (27\%) and lower scorer (27\%) in the discrimination index calculation process. In the analysis, the total test scores of the respondents were ranked in an ascending manner and DisCo was calculated using formula as suggested in Kiamanesh (2002) and Jandaghi (2010) is shown below.

$$
\operatorname{DisCoef}_{\text {question }(i)}=\frac{M_{S(i)}-M_{W(i)}}{n_{g} \times m_{i}}
$$

where

$M_{S(i)}=$ Sum of marks for strong group in question $i$.

$M_{W(i)}=$ Sum of marks for weak group in question $i$.

$n_{g}=$ Number of respondents in one group.

$m_{i}=$ Total mark of question $i$

The computed coefficient of item discrimination is indicated in Table 2. All items in FSCT show a DisCo range from 0.21 to 0.28, indicating that the items have good DisCo (Jandaghi, 2010). According to Ebel (1972), items with index greater than 0.20 was an acceptable range in discrimination indexes for item analysis.

\subsection{Internal Consistency}

In this research, internal consistency was measured in two methods. The first method was Pearson productmoment correlation coefficients between items. The item-total correlation was also calculated to check on items correlation with the total score in order to confirm that they were measuring the same thing as the other items (Table 3). The correlations between items varied from a weak 0.050 (between Item one and Item six) to a moderate 0.617 (between Item two and Item five). Overall, there was a significant, weak to moderate and positive

Table 1. Scoring criteria for trait dimension of scientific creativity.

\begin{tabular}{|c|c|c|}
\hline Trait dimension & Ability & Scoring Criteria \\
\hline Fluency & - Total number of relevant responses based on the item. & $\begin{array}{l}\text { • “ } 0 \text { ” irrelevant responses } \\
\text { • “ } 1 \text { ” relevant responses }\end{array}$ \\
\hline Originality & $\begin{array}{l}\text { - Produce ideas that are less expected, uncommon or } \\
\text { unique. }\end{array}$ & $\begin{array}{l}\text { - “ } 0 \text { ” respond greater than } 10 \% \\
\text { - “ } 1 \text { ” respond of } 5 \% \text { to } 10 \% \\
\text { - } \quad 2 \text { " respond of less than } 5 \%\end{array}$ \\
\hline Elaboration & - Develop and embellish ideas in figural images. & $\begin{array}{l}\text { - “ } 0 \text { ’ no details } \\
\text { - “ } 1 \text { ” for } 1 \text { to } 5 \text { details } \\
\text { - “2” for } 6 \text { to } 12 \text { details } \\
\text { - “ } 3 \text { ” for } 13 \text { to } 19 \text { details }\end{array}$ \\
\hline Abstractness of title & $\begin{array}{l}\text { - Produce good titles involves the thinking processes of } \\
\text { synthesis and organization. }\end{array}$ & $\begin{array}{l}\text { - “ } 0 \text { ” obvious or generic title } \\
\text { - “ } 1 \text { ” simple descriptive title at a concrete level. } \\
\text { - “ } 2 \text { ” imaginative, descriptive title that goes } \\
\text { beyond a concrete, physical description. } \\
\text { - “3” abstract but appropriate title }\end{array}$ \\
\hline $\begin{array}{l}\text { Resistance to } \\
\text { premature closure }\end{array}$ & $\begin{array}{l}\text { - Keep an open mind and work on available } \\
\text { information from a variety of perspectives. }\end{array}$ & $\begin{array}{l}\text { - " } 0 \text { " closed by the quickest and easiest way } \\
\text { - " } 1 \text { " goes beyond the simple closing with added } \\
\text { details outside the enclosure } \\
\text { - " } 2 \text { " closure is never completed or is completed } \\
\text { with irregular lines which form part of a figure }\end{array}$ \\
\hline
\end{tabular}


Table 2. Discrimination Coefficient of FSCT.

\begin{tabular}{cc}
\hline Item & Discrimination Coefficient \\
\hline One & 0.25 \\
Two & 0.38 \\
Three & 0.27 \\
Four & 0.29 \\
Five & 0.40 \\
Six & 0.22 \\
\hline
\end{tabular}

Table 3. Correlation Coefficients between Items Scores as well as Item and Total Score.

\begin{tabular}{rccccccc} 
& Item 1 & Item 2 & Item 3 & Item 4 & Item 5 & Item 6 & Total \\
\hline Item 1 & 1.000 & & & & & & \\
Item 2 & 0.488 & 1.000 & & & & & \\
Item 3 & 0.209 & 0.457 & 1.000 & & & & \\
Item 4 & 0.385 & 0.562 & 0.197 & 1.000 & & & \\
Item 5 & 0.290 & 0.617 & 0.603 & 0.582 & 1.000 & & \\
Item 6 & 0.050 & 0.361 & 0.212 & 0.404 & 0.492 & 1.000 & \\
Total & 0.541 & 0.842 & 0.634 & 0.749 & 0.866 & 0.567 & 1.000 \\
\hline
\end{tabular}

correlation between test items.

However, the item-total correlations varied from 0.541 to 0.866 . The results showed a moderate to strong relationship between items and total score. Soon (2008) stated that items should have reasonable high item-total correlations, as a rule of thumb, 0.3 and above is considered acceptable. All of the correlation coefficients in the research were made at confidence level of $95 \%$.

Secondly, the Cronbach's Alpha coefficient of internal consistency was computed to determine the degree to which the items on the same test, measure the same construct in order to produce a consistent result (Cohen, Manion, \& Morrison, 2007). Chua (2006) stated that alpha value within 0.65 and 0.95 was considered satisfactory. The alpha value of FSCT based upon scores of 30 preschool pupils was 0.806 . For a test with only six items, the value showed a very satisfactory indication of internal consistency. The corrected item-total correlation and Cronbach's alpha coefficients after each item was deleted were also calculated (Table 4). All the corrected item-total correlation and alpha values were less than that if the item was not removed except for Item one (0.807). After consulting the experts, they suggested that Item one should be remained as this item was suitable to measure scientific creativity among the preschool pupils. Consequently, this indicated that all the six items contributed to the central test construct of scientific creativity. Overall these results indicate that all the items consistently contributed similar result and these items be it individually or collectively measured the same domain.

\subsection{Inter-Rater Reliability}

Due to the subjectivity in interpreting the scoring criteria for scientific creativity, it was necessary for an independent person who had not involved in the instrument development to reliably interpret based on the same scoring system (Hu \& Adey, 2002). The scores for 30 preschool pupils were rated independently by a creativity researcher and the researcher. Pearson product-moment correlation coefficients between the two sets of scores are presented in Table 5. The correlations between scores varied from 0.780 to 0.933 . Hence, the results suggested that the scoring procedure was sufficiently objective.

\subsection{Construct Related Validity}

Guilford (1950) stated that factorial validity should be the first step in validating creativity test. Factorial validity 
Table 4. Corrected Item-Total Correlation and Cronbach Alpha if Item Deleted.

\begin{tabular}{ccc}
\hline & Corrected Item-Total Correlation & $\begin{array}{c}\text { Cronbach Alpha if Item Deleted } \\
\text { (whole test alpha }=0.806 \text { ) }\end{array}$ \\
\hline Item 1 & 0.398 & 0.807 \\
Item 2 & 0.723 & 0.736 \\
Item 3 & 0.482 & 0.791 \\
Item 4 & 0.611 & 0.765 \\
Item 5 & 0.753 & 0.723 \\
Item 6 & 0.438 & 0.801 \\
\hline
\end{tabular}

Table 5. Scorer Agreement between two raters.

\begin{tabular}{cc}
\hline & $\begin{array}{c}\text { Scorer Agreement } \\
(\mathrm{n}=30 \text { answer sheets })\end{array}$ \\
\hline Item 1 & 0.835 \\
Item 2 & 0.933 \\
Item 3 & 0.898 \\
Item 4 & 0.867 \\
Item 5 & 0.857 \\
Item 6 & 0.780 \\
\hline
\end{tabular}

is a form of construct validity determined by factor analysis of the test scores. In order to ascertain the construct related validity of FSCT, the exploratory factor analysis was run. The Kaiser-Meyer-Olkin (KMO) measure of sampling adequacy and Barlett's Test of Sphericity were run to determine whether further factorial analysis was appropriate (Table 6). Kaiser (1974) stated that values of KMO that greater than 0.5 were acceptable. FSCT obtained value of 0.735 , which was considered high. With reference to Table 6 , it could be concluded that the correlation patterns for the six items were relatively compact and able to yield distinct, reliable factors through factor analysis. Furthermore, this result was also supported by Barlett's test that showed significant values less than 0.001 . Thus, factor analysis was appropriate to be carried out.

The factor analysis was then executed on the data from the FSCT. The Principal Component Factor Analysis obtained consisted only one factor. The solutions could not be rotated, all items loaded from 0.542 to 0.867 on one factor which explained 50.8\% of the total variance (Table 7). According to Kline (1993), items selected for a unifactor test should load significantly on only one factor in the analysis, and the load should obtained larger than 0.3. Table 8 shows the factor loading of each item in FSCT. The results in the analysis suggested that FSCT has good construct related validity, measuring only one factor of scientific creativity.

\subsection{Content Validity}

In order to ascertain the content validity of the FSCT, the items were reviewed by subject matter experts. Experts in this research refer to University and collage lecturer as well as researcher in the field of creativity. A panel of four experts were involved (one of them was a creativity expert, two from science educational programs, and one was creativity's researcher). The experts were required to confirm the dimensions of scientific creativity (product, process and trait) measured in each item and provide written comments to improve the items. In accordance with the experts' suggestions, the necessary corrections were made for the language and appropriateness of the items.

\subsection{Face Validity}

Face validity refers to the relevance or transparency of an instrument as it appears to the test participants (Holden, 2010; Gravetter \& Forzano, 2012). To obtain a measure of face validity of FSCT, a total of ten science educators and preschool teachers from Kota Kinabalu, Sabah were asked to respond the question "Which items 
Table 6. Kaiser-Meyer-Olkin (KMO) and Barlett’s test.

\begin{tabular}{ccccc}
\hline & KMO Measure of Sampling Adequacy & \multicolumn{3}{c}{ Bartlett's Test of Sphericity } \\
& & Approx. Chi-Square & df & Sig. \\
\hline FSCT & 0.735 & 58.02 & 15 & 0.00 \\
\hline
\end{tabular}

Table 7. Factor extraction.

\begin{tabular}{rcccccc}
\hline & \multicolumn{3}{c}{ Initial Eigenvalues } & \multicolumn{2}{c}{ Extraction Sums of Squared Loadings } \\
\cline { 2 - 6 } & Total & \% of Variance & Cumulative \% & Total & \% of Variance & Cumulative \% \\
\hline Item 1 & 3.051 & 50.849 & 50.849 & 3.051 & 50.849 & 50.849 \\
Item 2 & 0.999 & 16.653 & 67.502 & & \\
Item 3 & 0.876 & 14.606 & 82.108 & & \\
Item 4 & 0.477 & 7.946 & 90.054 & & \\
Item 5 & 0.358 & 5.963 & 96.017 & 100.000 & & \\
Item 6 & 0.239 & 3.983 & &
\end{tabular}

Table 8. Factor loading of each item.

\begin{tabular}{cc}
\hline & Component \\
\hline Item 1 & 0.542 \\
Item 2 & 0.839 \\
Item 3 & 0.629 \\
Item 4 & 0.753 \\
Item 5 & 0.867 \\
Item 6 & 0.582 \\
\hline
\end{tabular}

in the FSCT can measure scientific creativity of the preschool pupils?”. The results are shown in Table 9, suggesting a high degree of face validity amongst science educators and preschool teachers.

\subsection{Acceptability to Pupils}

A test should have at least some level of acceptance by the pupils in order to be used successfully in assessing scientific creativity (Hu \& Adey, 2002). In this research, 30 preschool pupils tested were asked the question, 'Which items did you find interesting and uninteresting in the FSCT?' Results are shown in Table 10, indicating a high degree of acceptability by the preschool pupils.

\section{Discussion}

This research was a preliminary attempt to develop a FSCT and ascertain its reliability and validity. A six-item test was developed based on SCSM for measuring scientific creativity among the preschool pupils. The analysis on item discrimination, internal consistency, inter-rater reliability, construct related validity, content validity, face validity and acceptability to pupils indicated different levels of the test's power and suitability of the test.

Discrimination index obtained by each item of FSCT reached the threshold of an acceptable range. Overall internal consistency suggested that FSCT developed was with high reliability, as well as inter-scorer reliability. Inter-item correlations showed there was a significant, weak to moderate with positive correlation between test items. However, the item-total correlations showed a moderate to strong relationship between items and total score.

Creativity is a second order ability factor named "general fluency" or "retrieval capacity", which loads on ideational fluency, association fluency and irrelevant association's tests, and known as general retrieval power 
Table 9. Face validity amongst science educators and teachers.

\begin{tabular}{ccc}
\hline & Response $(\mathrm{n}=10)$ & \\
\hline Item & Can & Cannot \\
One & 10 & \\
Two & 10 & 2 \\
Three & 8 & 1 \\
Four & 9 & \\
Five & 10 & \\
Six & 10 & \\
\hline
\end{tabular}

Table 10. Preschool pupils’ acceptability to FSCT.

\begin{tabular}{ccc}
\hline & \multicolumn{2}{c}{ Preschool Pupils' Response $(\mathrm{n}=30)$} \\
\cline { 2 - 3 } Item & Interesting & Uninteresting \\
\hline One & 30 & 0 \\
Two & 30 & 0 \\
Three & 30 & 0 \\
Four & 29 & 1 \\
Five & 30 & 0 \\
Six & 28 & 2 \\
\hline
\end{tabular}

which accounts for a variety of skills (Horn \& Cattel, 1966). Guilford (1956) connected divergent production with creative thinking, where many alternative solutions to be brought to a given problem. Based on these researchers, scientific creativity as domain creativity should be unifactor measuring one factor of scientific creativity. Results from factor analysis of this study obtained only one factor, indicated that FSCT has good construct validity by measuring unifactor of scientific creativity. This result was similar to Hu and Adey's (2002) finding which also obtained a unifactor scientific creativity test for secondary school students. However, Siew, Chong and Chin (2014) found two factors in their developed scientific creativity test for primary school fifth grades, measuring scientific creativity and spatial analytical thinking.

\section{Conclusion}

The results of this research ascertained that the developed FSCT could be used to assess the scientific creativity of the six-year-old preschool pupils in preschools. However, more work needs to be done to further validate the instrument. More importantly, predictive validity should be determined. Test-retest reliability could be evaluated as well as relationship between this instrument with other general creativity could be included in study. Other studies may investigate the different samples using FSCT. Thus, the researchers believe that FSCT could be used to assess whether preschool pupils' scientific creativity can be fostered with a specific intervention programme and the factors that influence the development of preschool pupils' scientific creativity.

\section{Acknowledgements}

The research reported in this study was supported by the Universiti Malaysia Sabah, Malaysia under Grant No. FRG0394-SSI-2/2014. Any opinions, viewpoints, findings, conclusions, suggests, or recommendations expressed are the authors and do not necessarily reflect the views of the Universiti Malaysia Sabah, Malaysia.

\section{References}

Aktamış, H., \& Ergin, Ö. (2006). Fen Egitimive Yaratıcılık (Science Education and Creativity). Dokuz Eylul University Faculty of Education Journal, 20, 77-83. http://web.deu.edu.tr/befdergi/9.pdf 
Albert, R. S. (1983). Genius Eminence. New York: Pergamon.

Carson, S. H. (2011). Creativity and Psychopathology: A Shared Vulnerability Model. The Canadian Journal of Psychiatry, 56, 144-153.

Chua, Y. P. (2006). Methods and Statistics: Elementary Statistics Research. Kuala Lumpur: McGraw-Hill (Malaysia) Sdn. Bhd.

Coakes, S. J. (2005). SPSS. Singapore: John Wiley and Sons Australis. Ltd.

Cohen, L., Manion, L., \& Morrison, K. (2007). Research Methods in Education. London \& New York: Routledge, Taylor \& Francis Group.

Cox, J. R., \& Jones, B. W. (2011). External Representations in the Teaching and Learning of Introductory Chemistry. Creative Education, 2, 461-465. http://dx.doi.org/10.4236/ce.2011.25067

Csikszentmihalyi, M. (1996). Creativity: Flow and the Psychology of Discovery and Invention. New York: Harper Collins.

Curriculum Development Centre (2001). National Preschool Curriculum. Kuala Lumpur: Ministry of Education Malaysia.

Curriculum Development Centre (2010). National Pre-school Curriculum Standard. Kuala Lumpur: Ministry of Education Malaysia.

Davis, G., \& Rimm, S. (2004). Education of the Gifted and Talented (5th ed.). Needham Heights, MA: Allyn \& Bacon.

do Ouro Lopes Silva, G., Fadel, S. de J., \& Múglia Wechsler, S. (2013). Criatividade E Educação: Análise Da Produção Científica Brasileira [Creativity and Education: Analysis of the Brazilian Scientific Production]. ECCOS, 30, 165-181.

Ebel, R. L. (1972). Essentials of Educational Measurement (1st ed.). Upper Saddle River, NJ: Prentice Hall.

Feldman, D. H. (1986). Nature's Gambit. New York: Basic Books.

Gardner, H. (1983). Frames of Mind: The Theory of Multiple Intelligence. New York: Basic Books.

Gardner, H. (2010). Five Minds for the Future. Cambridge, MA: Harvard Business School Press.

Gravetter, F. J., \& Forzano, L. B. (2012). Research Methods for the Behavioral Sciences (4th ed.). Belmont, CA: Wadsworth.

Guilford, J. P. (1956). The Structure of Intellect. Psychological Bulletin, 53, 267-293. http://dx.doi.org/10.1037/h0040755

Han, K. (2003). Domain-Specificity of Creativity in Young Children: How Quantitative and Qualitative Data Support It. Journal of Creative Behavior, 37, 117-142. http://dx.doi.org/10.1002/j.2162-6057.2003.tb00829.x

Holden, R. B. (2010). Face Validity. In I. B. Weiner, \& W. E. Craighead (Eds.), The Corsini Encyclopedia of Psychology (4th ed.). Hoboken, NJ: Wiley. http://dx.doi.org/10.1002/9780470479216.corpsy0341

Horn, J., \& Cattel, R. B. (1966). Refinement and Tests of the Theory of Fluid and Crystal-Lised Intelligence. Journal of Educational Psychology, 57, 253-270. http://dx.doi.org/10.1037/h0023816

Hu, W., \& Adey, P. (2002). A Scientific Creativity Test for Secondary School Students. International Journal of Science Education, 24, 389-403. http://dx.doi.org/10.1080/09500690110098912

Jandaghi, G. (2010). Assessment of Validity, Reliability and Difficulty Indices for Teacher-Built Physics Exam Questions in First Year High School. Educational Research and Review, 5, 651-654.

Kaiser, H. F. (1974). An Index of Factorial Simplicity. Psychometrika, 39, 31-36. http://dx.doi.org/10.1007/BF02291575

Kaufman, J. C., \& Baer, J. (2008). Role of the Domain in Creative Learning in USA. In A. R. Craft, T. Cremin, \& P. Burnard (Eds.), Creative Learning 3-11 and How We Document It (pp. 27-34). Staffordshire: Trentham Books.

Kiamanesh, A. R. (2002). Assessment and Evaluation in Physics. Tehran: Ministry of Education Publications.

Kline, P. (1993). The Handbook of Psychological Testing. London: Routledge.

Liang, J. (2002). Exploring Scientific Creativity of Eleventh Grade Students in Taiwan. PhD Thesis, Austin, TX: University of Texas.

Lubart, T. I. (1994). Creativity. In R. J. Sternberg (Ed.), Handbook of Perception and Cognition: Thinking and Problem Solving (pp. 289-332). New York: Academic Press.

Matlock-Hetzel, S. (1997). Basic Concepts in Item and Test Analysis. Paper presented at the Annual Meeting of the Southwest Educational Research Association, Austin, 23-25 January 1997.

Meador, K. S. (1997). Creative Thinking and Problem Solving for Young Learners. Englewood, CO: Teacher Ideas Press.

Ministry of Education Malaysia (2012). Malaysia Education Blueprint 2013-2025. Kuala Lumpur: Ministry of Education Malaysia.

Mohamed, A. (2006). Investigating the Scientific Creativity of Fifth-Grade Students. PhD Thesis, Tucson, AZ: University of Arizona.

Nickerson, R. S. (1999). Enhancing Creativity. In R. J. Sternberg (Ed.), Handbook of Creativity (pp. 392-410). Cambridge, UK: Cambridge University Press. 
Okuda, S. M., Runco, M. A., \& Berger, D. E. (1991). Creativity and the Finding and Solving of Real-Life Problems. Journal of Psychoeducational Assessment, 9, 45-53. http://dx.doi.org/10.1177/073428299100900104

Pink, D. (2005). A Whole New Mind. New York: Riverhead Trade.

Siew, N. M., \& Chong, C. L. (2014). Fostering Students' Creativity Through Van Hiele’s 5 Phase-Based Tangram Activities. Journal of Education and Learning, 3, 66-80. http://dx.doi.org/10.5539/jel.v3n2p66

Siew, N. M., Chong, C. L., \& Chin, K. M. (2014). Developing a Scientific Creativity Test for Fifth Graders. Problems of Education in the 21st Century, 62, 109-123.

Soon, S. T. (2008). Data Analysis and Interpretation Using SPSS. Education Planning \& Research Division, Kuala Lumpur: Ministry of Education.

Sriraman, B. (2005). Are Giftedness and Creativity Synonyms in Mathematics? The Journal of Secondary Gifted Education, $17,20-36$.

Torrance, E. P., Ball, O. E., \& Safter, H. T. (2008). Torrance Test of Creative Thinking: Streamlined Scoring Guide for Figural Forms A and B. Bensenville, IL: Scholastic Testing Service, Inc.

Torrance, E. P. (1990). Torrance Test of Creative Thinking. Bensenville, IL: Scholastic Testing Services. 